\title{
A Novel Quantitative Electrochemical Method to Monitor DNA Double-Strand Breaks Caused by a DNA Cleavage Agent at a DNA Sensor
}

\author{
Anna Banasiak \\ Technological University Dublin \\ John Cassidy \\ Technological University Dublin, john.cassidy@tudublin.ie \\ John Colleran \\ Technological University Dublin, john.colleran@tudublin.ie
}

Follow this and additional works at: https://arrow.tudublin.ie/scschcpsart

Part of the Chemistry Commons

\section{Recommended Citation}

Banasiak, A., Cassidy, J., Colleran, J. (2018). A novel quantitative electrochemical method to monitor DNA double-strand breaks caused by a DNA cleavage agent at a DNA sensor. Biosensors and Bioelectronics, 117, pp.217-223. doi:10.1016/j.bios.2018.05.058

This Article is brought to you for free and open access by the School of Chemical and Pharmaceutical Sciences at ARROW@TU Dublin. It has been accepted for inclusion in Articles by an authorized administrator of ARROW@TU

Dublin. For more information, please contact

arrow.admin@tudublin.ie, aisling.coyne@tudublin.ie, gerard.connolly@tudublin.ie.

Funder: Technological University Dublin

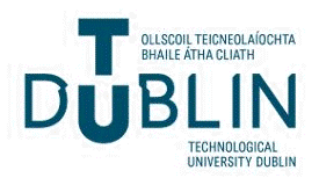




\title{
A Novel Quantitative Electrochemical Method to Monitor DNA Double-Strand Breaks Caused by a DNA Cleavage Agent at a DNA Sensor
}

\author{
Anna Banasiak $^{\mathrm{a}}$, John Cassidy ${ }^{\mathrm{a}, \mathrm{b}}$, John Colleran ${ }^{\mathrm{a}, \mathrm{b}, *}$ \\ ${ }^{a}$ Applied Electrochemistry Group, Dublin Institute of Technology, FOCAS Institute, Camden \\ Row, Dublin 8, Ireland \\ ${ }^{b}$ School of Chemical and Pharmaceutical Sciences, Dublin Institute of Technology, Kevin \\ Street, Dublin 8, Ireland \\ *Corresponding author. Tel: +353 1402 4682; E-mail: john.colleran@ dit.ie
}

\begin{abstract}
To date, DNA cleavage, caused by cleavage agents, has been monitored mainly by gel and capillary electrophoresis. However, these techniques are time-consuming, non-quantitative and require gel stains. In this work, a novel, simple and, importantly, a quantitative method for monitoring the DNA nuclease activity of potential anti-cancer drugs, at a DNA electrochemical sensor, is presented. The DNA sensors were prepared using thiol-modified oligonucleotides that self-assembled to create DNA monolayers at gold electrode surfaces. The quantification of DNA double-strand breaks is based on calculating the DNA surface coverage, before and after exposure to DNA cleavage agents, using a method developed by a Tarlov group. The nuclease properties of a model DNA cleavage agent, copper bisphenanthroline $\left(\left[\mathrm{Cu}^{\mathrm{II}}(\text { phen })_{2}\right]^{2+}\right)$, that cleaves DNA in a Fenton-type reaction, were quantified electrochemically. The DNA surface coverage decreased on average by $21 \%$ after immersing the DNA sensor in a nuclease assay containing $\left[\mathrm{Cu}^{\mathrm{II}}(\text { phen })_{2}\right]^{2+}$, a reductant and an oxidant. This percentage indicates that 6 base pairs were cleaved in the nuclease assay from the immobilised 30 base pair strands. The DNA cleavage can be also induced electrochemically in the absence of a chemical reductant. $\left[\mathrm{Cu}^{\mathrm{II}}(\text { phen })_{2}\right]^{2+}$, intercalates between DNA base pairs and, on application of a suitable potential, can be reduced to $\left[\mathrm{Cu}^{\mathrm{I}}(\mathrm{phen})_{2}\right]^{+}$, with solution oxygen acting as the required oxidant. This reduction process is facilitated through DNA strands via long-range electron transfer, resulting in DNA cleavage of $23 \%$. The control measurements for both chemically and electrochemically induced cleavage revealed that DNA strand breaks did not occur under experimental conditions in the absence of $\left[\mathrm{Cu}^{\mathrm{II}}(\text { phen })_{2}\right]^{2+}$.
\end{abstract}

Keywords: DNA cleavage, DNA biosensor, DNA cleavage agent, DNA interaction, copper bis-phenanthroline, DNA quantitation.

Declaration of interest: none. 


\section{Introduction}

Many compounds can interact with DNA and cause significant DNA damage that can lead to the inhibition of DNA replication, eventually promoting cell death (Gibson, 2002; Patrick, 2013). Compounds that promote cell death can be used in anticancer therapies to kill cancer cells. One type of said compounds is DNA cleavage agents. These compounds can interact with DNA through an intercalation or a groove binding mechanism and, additionally, can generate reactive oxygen and nitrogen species. Radicals, especially hydroxyl radicals, damage DNA bases and can cleave DNA chains (Gowda et al., 2014; Prisecaru et al., 2013).

Interactions between DNA and compounds can be investigated using electrochemical DNA sensors. These sensors consist of DNA as a biorecognition element and an electrode as a transducer (Drummond et al., 2003). The DNA strands immobilised on the electrode surface can facilitate the electron transfer between the electrode surface and redox active molecules that interact with DNA. Electron transfer in DNA can be observed over distances as great as $200 \AA$ and is termed long-range electron transfer (Liu and Barton, 2005; Treadway et al., 2002).

Electrochemical DNA sensors have been widely used to investigate the interactions between DNA and a myriad of potential and current drugs (Abreu et al., 2002; Brabec, 2000; Congur et al., 2015; Diculescu et al., 2006; Erdem and Congur, 2013; Erdem and Ozsoz, 2001; Fojta et al., 2000a; Janiszek et al, 2016; Jelen et al., 2002; La-Scalea et al., 2002; Marin et al., 1998; Oliveira-Brett et al., 1996, 1998, 2002; Perez et al., 1999; Wang et al., 1998). These studies are based on changes in the electrochemical signal of DNA and the compound before and after the interaction (Diculescu et al., 2016; Erdem and Ozsoz, 2002; Fojta, 2002a; Fojta et al., 2016; Palecek and Bartosik, 2012). For example, Brabec (2000) reported a decrease of the guanine oxidation peak at a DNA-coated paraffin-wax graphite electrode after interaction with platinum compounds. This decrease indicates that interactions occur between guanine residues of DNA and platinum compounds.

DNA cleavage, caused by interaction with DNA cleavage agents or proteins has, to date, been monitored mainly by electrophoresis (Molphy et al., 2014, 2015; Prisecaru et al., 2012, 2013; Reddy et al., 1999; Rodriquez et al., 1990). Typically, DNA is mixed with the chosen compound and, after a given time, the cleaved DNA fragments are analysed using gel or capillary electrophoresis. This method is time-consuming, non-quantitative and requires gel stains.

The electrochemical monitoring of DNA cleavage is also possible. The main advantages of the electrochemical approach are its simplicity, low cost, high sensitivity, minimal power requirements and suitability for automation.

Labuda et al. (1998) detected DNA damage caused by reactive oxygen species at a glassy carbon electrode using $\left[\mathrm{Co}(\mathrm{phen})_{3}\right]^{3+}$ as a redox marker. Double-stranded DNA (dsDNA) was treated with a mixture known to generate radicals - $\mathrm{Cu}$ (II) complex, a reducing agent, and air. The DNA was then adsorbed onto the GCE surface and changes in the DNA structure were monitored, using cyclic voltammetry, through changes in the electrochemical response of the redox marker, $\left[\mathrm{Co}(\text { phen })_{3}\right]^{3+}$. Reactive oxygen species can damage DNA base pairs that lead to the creation of DNA base pair derivatives, such as electroactive 8-oxo-7,8dihydroguanine (8-oxoG). Oliveira-Brett et al. (2002) together with Diculescu (2004) and Oliveira (2010) monitored DNA oxidative damage through the appearance of an 8-oxoG signal at a glassy carbon electrode using differential pulse voltammetry. Lloyd et al. (1998) reported that the formation of 8-oxoG in DNA is correlated with formation of double-strand breaks in the strands. The registration of 8-oxoG oxidation peak at the electrode can then be, in theory, used to detect the DNA cleavage caused by DNA cleavage agents. Similarly, Fojta et al. (1997, 1998, 1999, 2000b, 2002b) registered DNA cleavage caused by reactive oxygen species using supercoiled DNA-modified mercury electrodes. After immersing the DNA 
sensor in the nuclease assays, additional signals associated with open circular and linear forms of DNA were observed using AC voltammetry. Hence, DNA cleavage can be monitored using different electrochemical methods, different types of DNA and using different electrode types. However, to our knowledge, none of these methods facilitate quantitative studies of DNA cleavage.

In this paper, we introduce a novel, simple and quantitative method to monitor the nuclease activity of DNA cleavage agents using a DNA electrochemical sensor. This method is based on calculating the DNA surface coverage before and after exposure to a DNA cleavage agent. The DNA surface coverage was calculated using a method developed by a Tarlov group (Steel et al., 1998). In this work, $\left[\mathrm{Cu}^{\mathrm{II}}(\text { phen })_{2}\right]^{2+}$ was used as a model DNA cleavage agent. $\left[\mathrm{Cu}^{\text {II }}(\text { phen })_{2}\right]^{2+}$ can intercalate unselectively between the DNA base pairs through the phenanthroline rings and can also be attracted electrostatically by the negatively charged phosphate groups of the DNA backbone. The nuclease activity of $\left[\mathrm{Cu}^{\mathrm{II}}(\mathrm{phen})_{2}\right]^{2+}$ was discovered in 1980's (Marshall et al., 1981; Que et al., 1980; Sigman et al., 1979), and this compound displays DNA cleavage properties under specific conditions. In the presence of an oxidant and reductant, $\left[\mathrm{Cu}^{\mathrm{II}}(\text { phen })_{2}\right]^{2+}$ can cause double-strand breaks in DNA (Que et al., 1980). It is thought that the role of the reductant is to reduce $\left[\mathrm{Cu}^{\mathrm{II}}(\text { phen })_{2}\right]^{2+}$ to $\left[\mathrm{Cu}^{\mathrm{I}}(\text { phen })_{2}\right]^{+}$ and the oxidant then interacts with the reduced form of copper bis-phenanthroline in a Fenton - type reaction (Molphy et al., 2014; Prisecaru et al., 2012, 2013).

$$
\begin{aligned}
& {\left[\mathrm{Cu}^{\mathrm{II}}(\text { phen })_{2}\right]^{2+}+\text { reductant } \longrightarrow\left[\mathrm{Cu}^{\mathrm{I}}(\text { phen })_{2}\right]^{+}} \\
& {\left[\mathrm{Cu}^{\mathrm{I}}(\text { phen })_{2}\right]^{+}+\mathrm{H}_{2} \mathrm{O}_{2} \longrightarrow\left[\mathrm{Cu}^{\mathrm{II}}(\text { phen })_{2}\right]^{2+}+\mathrm{HO}^{\circ}+\mathrm{HO}^{-}}
\end{aligned}
$$

In this paper, DNA cleavage was induced both chemically, using ascorbic acid and hydrogen peroxide, and electrochemically, through the application of a cathodic potential at DNA sensors immersed in $\left[\mathrm{Cu}^{\mathrm{II}}(\mathrm{phen})_{2}\right]^{2+}$ solutions.

\section{Experimental}

\subsection{Materials}

The 30 base pair DNA oligonucleotides (Oligo DNA) were purchased from Sigma-Aldrich. Three different DNA oligonucleotides were used, having the following sequences:

Thiol-modified sequence: SH- $\left(\mathrm{CH}_{2}\right)_{6}$ - 5'AGTACAGTCATCGCTTAATTATCGTACGTA3' Complementary sequence: 5'TCATGTCAGTAGCGAATTAATAGCATGCAT3'

DNA with A-T rich region in the middle of the strand:

HS- $\left(\mathrm{CH}_{2}\right)_{6}-5$ 'AGTACAGTCGGTTAATACAGTCGTCTAAGC3'

Complementary to A-T: 5'TCATGTCAGCCAATTATGTCAGCAGATTCG3'

DNA with G-C rich region in the middle of the strand:

HS- $\left(\mathrm{CH}_{2}\right)_{6}-5$ 'AGTACAGTCATGGCGGCACAGTCTTCGGTA3'

Complementary to G-C: 5'TCATGTCAGTACCGCCGTGTCAGAAGCCAT3'

Ruthenium (III) hexammine trichloride and p-toluenethiol were purchased from Fisher. All other chemicals were purchased from Sigma-Aldrich. Argon gas was purchased from Air Products. Nuclease-free water was used to prepare 1xTE buffer which consisted of $10 \mathrm{mM}$ Tris-HCl, $\mathrm{pH} \mathrm{8.0,} \mathrm{and} 1 \mathrm{mM}$ EDTA, $\mathrm{pH}$ 8.0, that served in the dilution of Oligo DNA and in the hybridisation of the Oligo DNA strands. All other solutions were prepared using ultrapure water purified with a Milli- $\mathrm{Q}^{\circledR}$ system. 


\subsection{Equipment}

The electrochemical measurements were performed with a $\mathrm{CH}$ Instruments Potentiostat, model 620A. A Solartron 1285 Potentiostat was used to apply a constant potential in some experiments. Gold disc electrodes ( $2 \mathrm{~mm}$ diameter), modified with an immobilised DNA selfassemble monolayer (SAM), were used as the working electrodes. Saturated calomel and silver/silver chloride were used as reference electrodes, and a platinum wire as the counter electrode. The supporting electrolyte was deoxygenated with argon for $15 \mathrm{~min}$ before experiments. A blanket of argon was maintained above the solution during measurements to keep the solutions deoxygenated. DNA nuclease assays were performed at $37^{\circ} \mathrm{C}$ to simulate biological conditions while all electrochemical quantitative measurements were performed at room temperature.

\subsection{Preparation of DNA sensors}

Oligo DNA was hybridised directly before use in accordance with protocol provided by Sigma-Aldrich (Sigma-Aldrich website). Briefly, the thiol-modified Oligo DNA strands and complementary Oligo DNA strands were diluted to $10 \mu \mathrm{M}$ concentrations in 1xTE buffer, $\mathrm{pH}$ 8.0 , containing $50 \mathrm{mM} \mathrm{NaCl}$. The solution temperature was maintained at $94^{\circ} \mathrm{C}$ for $4 \mathrm{~min}$ using a heating block and later allowed to cool to room temperature on the lab bench.

The gold electrodes were cleaned by manual polishing on a soft polishing micro-cloth (Buehler) with $0.05 \mu \mathrm{m}$ alumina powder (Buehler) for $5 \mathrm{~min}$, followed by electrochemical cycling in $1 \mathrm{M}$ deaerated $\mathrm{H}_{2} \mathrm{SO}_{4}$ over the potential range $-0.2 \mathrm{~V}$ to $+1.5 \mathrm{~V}$ vs. SCE until stable, reproducible current profiles were achieved.

The freshly cleaned electrodes were immersed in $0.5 \mathrm{M}$ phosphate buffer, $\mathrm{pH} 7.0$, containing $0.4 \mu \mathrm{M}$ double-stranded Oligo DNA and left overnight. Resulting in the creation of a DNA SAM gold electrode (Pividori et al., 2000). The orientation of DNA strands can be manipulated somewhat by application of a suitable potential (Erts et al., 2003; Kelley et al., 1998; Zhang et al., 2002). Strands at the electrode surface were then, in theory, aligned to a more perpendicular position by applying a slight cathodic potential (-0.6 V vs. SCE) at the DNA sensor for $30 \mathrm{~s}$. The electrodes were then immersed in $1 \mathrm{mM}$ p-toluenethiol solution for 1 hour to backfill any 'pin holes' remaining between Oligo DNA strands after immobilisation. This avoids any non-specific interactions between analytes and the bare gold electrode. Moreover, thiols are believed to remove DNA strands that adsorb onto the electrode surface non-specifically, i.e. through physical adsorption, resulting in a conformation where DNA strands are bound only through the sulfur atom (Herne and Tarlov, 1997; Steel et al., 2000). Aromatic thiols, such as p-toluenethiol, were recently reported to be more effective back-filling agents than alkanethiols, such as 6-mercapto-1-hexanol (MouraMelo et al., 2015).

The beakers used during the immobilisation step were silanised prior to use as Oligo DNA is known to adsorb onto glass surfaces (Ausubel et al., 1989) (S-1, Supplementary Information).

\subsection{Quantification of DNA strands on the electrode surface}

An electrochemical method to quantitatively determine the DNA surface coverage was first introduced by the Tarlov group in 1998 (Steel et al., 1998). In general, negatively charged phosphate groups on DNA are charge compensated by cations present in solution. In low ionic strength electrolyte $(10 \mathrm{mM}$ Tris- $\mathrm{HCl})$, multivalent cations, such as the redox probe ruthenium (III) hexammine trichloride (RuHex), can replace cations presented within the DNA, such as $\mathrm{Na}^{+}$or $\mathrm{K}^{+}$. RuHex, stays within the DNA layer due to electrostatic attraction to the anionic phosphate residues of DNA. The amount of adsorbed RuHex molecules can be determined using chronocoulometry (CC). The number of adsorbed RuHex can then be translated into the number of DNA molecules adsorbed at the electrode surface if the number 
of nucleotides and, thus, the number of phosphate groups are known. One RuHex ion is ionpaired to three phosphate groups (Steel et al., 1998).

In the chronocoulometry technique the charge passed, on the application of the final potential, is measured as a function of time. On application of a sufficiently cathodic potential, RuHex bound to DNA is reduced $\left(\left[\mathrm{Ru}^{\mathrm{III}}\left(\mathrm{NH}_{3}\right)_{6}\right]^{3+}+\mathrm{e}^{-} \rightarrow\left[\mathrm{Ru}^{\mathrm{II}}\left(\mathrm{NH}_{3}\right)_{6}\right]^{2+}\right)$. The total charge $\left(\mathrm{Q}_{\text {total }}\right)$ measured during a $\mathrm{CC}$ experiment consists of the charge of the double-layer $\left(\mathrm{Q}_{\mathrm{dl}}\right)$, the charge of RuHex adsorbed in DNA layer $\left(\mathrm{Q}_{\mathrm{ads}}\right)$ and the charge of RuHex present in the solution $\left(\mathrm{Q}_{\mathrm{diff}}\right)$. The total charge is then described by the Anson equations:

$$
\begin{gathered}
\mathrm{Q}_{\text {total }}=\mathrm{Q}_{\mathrm{dl}}+\mathrm{Q}_{\mathrm{ads}}+\mathrm{Q}_{\text {diff }} \\
\mathrm{Q}_{\text {total }}=\mathrm{Q}_{\mathrm{dl}}+\mathrm{nFA} \Gamma_{0}+\left[\left(2 \mathrm{nFAD}{ }^{1 / 2} \mathrm{C}\right) / \pi^{1 / 2}\right] \mathrm{t}^{1 / 2}
\end{gathered}
$$

where $\mathrm{n}$ is the number of electrons involved in the redox probe reduction, $\mathrm{F}$ is the Faraday constant $\left(\mathrm{C} \cdot \mathrm{mol}^{-1}\right), \mathrm{A}$ is the electrode area $\left(\mathrm{cm}^{2}\right), \Gamma_{0}$ is the surface concentration of trapped electroactive $\left(\left[\mathrm{Ru}^{\mathrm{III}}\left(\mathrm{NH}_{3}\right)_{6}\right]^{2+}\right)$ within the dsDNA layer $\left(\mathrm{mol} \cdot \mathrm{cm}^{-2}\right)$, D is the diffusion coefficient of the redox active analyte in solution $\left(\mathrm{cm}^{2} \cdot \mathrm{s}^{-1}\right), \mathrm{C}$ is the bulk concentration of the redox active analyte in solution $\left(\mathrm{mol} \cdot \mathrm{cm}^{-3}\right)$, and $\mathrm{t}$ is time $(\mathrm{s})$.

A plot of charge versus the square root of time is constructed for the DNA sensor in the absence and presence of increasing concentrations of RuHex and the intercept is obtained for each measurement. The intercept in the absence of RuHex yields the charge of the double layer $\left(\mathrm{Q}_{\mathrm{dl}}\right)$, while the intercept obtained from a RuHex solution is the sum of the charge of the double layer and the charge of RuHex adsorbed in DNA layer $\left(\mathrm{Q}_{\mathrm{dl}}+\mathrm{Q}_{\mathrm{ads}}\right)$. $\mathrm{Q}_{\mathrm{diff}}$ can be ignored because it depends on time and ' $t$ ' (time) is equal zero at the intercept. The difference in intercepts is equal to the charge of RuHex adsorbed in the DNA layer $\left(\mathrm{Q}_{\mathrm{ads}}\right)$. This charge increases with increasing RuHex concentration until the layer is saturated with ions, resulting in a charge plateau. The plot $\mathrm{Q}_{\text {ads }}$ versus concentration of RuHex fits the Langmuir adsorption isotherm model. For the Langmuir model, the plot $\mathrm{C} / \mathrm{Q}_{\text {ads }}$ versus $\mathrm{C}$ (where $\mathrm{C}$ is the concentration of RuHex) shows a linear relationship (Li et al., 2014). The reduction charge of RuHex obtained for a saturated DNA layer $\left(\mathrm{Q}_{\text {sat }}\right)$ can then be calculated from the slope (equation 3) (Steel et al., 1999; Yu et al., 2003). Additionally, this equation can also be used to calculate the binding constant $(\mathrm{K})$ for the chosen complex.

$$
\mathrm{C} / \mathrm{Q}_{\mathrm{ads}}=\mathrm{C} / \mathrm{Q}_{\mathrm{sat}}+1 /\left(\mathrm{KQ}_{\mathrm{sat}}\right)
$$

$\mathrm{Q}_{\text {sat }}$ is used to calculate the surface concentration of RuHex adsorbed in DNA layer $\left(\Gamma_{0}\right)$ using the equation:

$$
\Gamma_{0}=\mathrm{Q}_{\mathrm{sat}} /(\mathrm{nFA})\left[\mathrm{mol} \cdot \mathrm{cm}^{-2}\right]
$$

If RuHex saturates the DNA layer and the number of phosphate groups (nucleotides) in the strand is known, the amount of adsorbed ions can be related to the DNA surface coverage $\left(\Gamma_{\text {DNA }}\right)$ :

$$
\Gamma_{\mathrm{DNA}}=\left(\Gamma_{0} \mathrm{ZN} \mathrm{A}\right) / \mathrm{m}\left[\text { molecules } \cdot \mathrm{cm}^{-2}\right]
$$

where $\mathrm{z}$ is the charge of bound ions, $\mathrm{m}$ is the number of nucleotides in the Oligo DNA strands, and $\mathrm{N}_{\mathrm{A}}$ is Avogadro's number (molecules $\cdot \mathrm{mol}^{-1}$ ). 


\subsection{Electrochemical conditions}

Cyclic voltammetry was carried out over the potential range $+0.1 \mathrm{~V}$ to $-0.35 \mathrm{~V}$ vs. SCE at a scan rate of $0.1 \mathrm{~V} \cdot \mathrm{s}^{-1}$. Chronocoulometry was carried out over the potential range $+0.1 \mathrm{~V}$ to $-0.6 \mathrm{~V}$ vs. SCE, pulse width $0.5 \mathrm{~s}$.

\section{Results and discussion}

\subsection{Interactions between DNA and $\left[\mathrm{Cu}^{\mathrm{II}}(\text { phen })_{2}\right]^{2+}$ at the DNA sensor}

$\left[\mathrm{Cu}^{\mathrm{II}}(\text { phen })_{2}\right]^{2+}$ is a known intercalator. Moreover, it has been reported that $\left[\mathrm{Cu}^{\mathrm{II}}(\mathrm{phen})_{2}\right]^{2+}$, after interaction with a reductant and oxidant, can generate hydroxyl radicals in close proximity to DNA strands, resulting in DNA double-strand breaks (Prisecaru et al., 2012).

First the DNA sensors were used to establish the interactions between DNA and the model nuclease compound, $\left[\mathrm{Cu}^{\mathrm{II}}(\text { phen })_{2}\right]^{2+}$. The DNA sensor was immersed in deaerated $0.1 \mathrm{M}$ phosphate buffer (PB), pH 7.0, containing $20 \mu \mathrm{M}\left[\mathrm{Cu}^{\mathrm{II}}(\mathrm{phen})_{2}\right]^{2+}$. The obtained results were compared to $\mathrm{CV}$ profiles registered at the bare gold electrode in the same solution (Figure 1).

\section{Here Figure 1}

The $\left[\mathrm{Cu}^{\mathrm{II}}(\mathrm{phen})_{2}\right]^{2+}$ oxidation and reduction waves were broad and ill-defined at the bare gold electrode, while clearly visible and defined at the DNA sensor. At the bare electrode, an anodic wave $\left(\mathrm{Cu}^{\mathrm{I}} / \mathrm{Cu}^{\mathrm{II}}\right)$ is observed at $-0.084 \mathrm{~V}$ and a coupled cathodic wave $\left(\mathrm{Cu}^{\mathrm{II}} / \mathrm{Cu}^{\mathrm{I}}\right)$ at $-0.200 \mathrm{~V}$ vs. SCE. The separation of the anodic and cathodic peak potentials, $\Delta \mathrm{E}_{\mathrm{p}}$, was $116 \mathrm{mV}$ which indicates a quasi-reversible reaction for a $1 \mathrm{e}^{-}$redox process. The formal potential, $\mathrm{E}^{\mathrm{o}}$, estimated as the average of peak potentials of both waves, was $-58 \mathrm{mV}$ at the bare gold electrode. At the DNA sensor, an anodic wave was observed at $-0.079 \mathrm{~V}$ and the coupled cathodic wave at $-0.113 \mathrm{~V}$ vs. SCE, giving a $\Delta \mathrm{E}_{\mathrm{p}}$ value of $34 \mathrm{mV}$. A $\Delta \mathrm{E}_{\mathrm{p}}$ value of $34 \mathrm{mV}$ is less than the $59 \mathrm{mV}$ value predicted for a diffusion-controlled reversible $1 \mathrm{e}^{-}$redox process. This result indicates that $\left[\mathrm{Cu}^{\mathrm{II}}(\text { phen })_{2}\right]^{2+}$ interacts (adsorbed) with DNA and can be reduced and oxidised through long-range electron transfer between the compound and the electrode. This electron transfer is facilitated through the DNA base pairs. The formal potential for $\mathrm{Cu}^{\mathrm{II}} / \mathrm{Cu}^{\mathrm{I}}$ redox reaction at the DNA sensor was approximated to be $-17 \mathrm{mV}$. Carter et al. (1989) reported that if the formal potential shifts to more positive values in the presence of DNA, the complex interacts with DNA predominantly through intercalation, as opposed to electrostatic attraction. In this case, the formal potential shifted anodically by $41 \mathrm{mV}$. Moreover, the oxidation and reduction waves disappeared after washing the sensor in $0.1 \mathrm{M} \mathrm{PB}, \mathrm{pH} 7.0$, for 20 minutes (Figure 1 - squared trace). This result also indicates that $\left[\mathrm{Cu}^{\mathrm{II}}(\text { phen })_{2}\right]^{2+}$ interacts with the Oligo DNA SAM through non-covalent interactions, indicative of intercalation and electrostatic attraction. Carter et al. (1989) also reported that the ratio of equilibrium constants for the binding of the reduced and oxidized forms of the complex to DNA, in solution, can be calculated from shifts in peak potentials (equation 6). In this paper, the equation was adopted to calculate the ratio of equilibrium constants for interactions occurring at DNA sensor, assuming reversibility.

$$
\mathrm{E}^{\mathrm{o}}{ }_{\mathrm{b}}-\mathrm{E}^{\mathrm{o}}{ }_{\mathrm{f}}=0.059 \log \left(\mathrm{K}_{\mathrm{red}} / \mathrm{K}_{\mathrm{ox}}\right)
$$

where $\mathrm{E}^{\mathrm{o}}{ }_{\mathrm{b}}$ is the formal potential registered for the complex in the presence of DNA, $\mathrm{E}^{\mathrm{o}}{ }_{\mathrm{f}}$ is the formal potential registered for the complex at the bare electrode surface (a free form of the complex), and $\mathrm{K}_{\mathrm{red}}$ and $\mathrm{K}_{\mathrm{ox}}$ are the equilibrium constants of the reduced and oxidized forms of the $\left[\mathrm{Cu}(\text { phen })_{2}\right]^{2+}$, respectively.

Thus, for the shift in $\mathrm{E}^{\mathrm{o}}$, registered at the DNA sensor for $\left[\mathrm{Cu}^{\mathrm{II}}(\text { phen })_{2}\right]^{2+}(+41 \mathrm{mV}) \mathrm{K}_{\mathrm{red}} / \mathrm{K}_{\mathrm{ox}}$ was determined to be 4.95 . This indicates that the reduced form of the complex, $\left[\mathrm{Cu}^{\mathrm{I}}(\mathrm{phen})_{2}\right]^{+}$, is 
bound almost five times stronger than the oxidized form, $\left[\mathrm{Cu}(\mathrm{II} / \mathrm{phen})_{2}\right]^{2+}$. This indicates that electrostatic interactions between DNA and $\left[\mathrm{Cu}^{\mathrm{II}}(\text { phen })_{2}\right]^{2+}$ are not predominant mode of action in these conditions, and hence, $\left[\mathrm{Cu}^{\mathrm{II}}(\mathrm{phen})_{2}\right]^{2+}$ binds intercalatively to DNA.

Additionally, the $\left[\mathrm{Cu}^{\mathrm{II}}(\mathrm{phen})_{2}\right]^{2+}$ redox wave peak currents obtained at the DNA sensor were recorded as a function of scan rate (Fig. S1, Supplementary Information). The resulting linear relationship between redox peak current and scan rate indicates that electron transfer between $\left[\mathrm{Cu}^{\mathrm{II}}(\text { phen })_{2}\right]^{2+}$ and the DNA sensor is under adsorption control. However, at the bare gold electrode, a linear relationship between the reduction peak current of $\left[\mathrm{Cu}^{\mathrm{II}}(\mathrm{phen})_{2}\right]^{2+}$ and the square root of scan rate was observed, indicating that the redox reaction occurring at the bare gold electrode is diffusion-controlled (Fig. S2, Supplementary Information). During the course of these experiments, $\left[\mathrm{Cu}^{\mathrm{II}}(\text { phen })_{2}\right]^{2+}$ interacts with DNA at the electrode surface and remains within the DNA layer.

\subsection{Chemically induced DNA cleavage}

To monitor the double-strand breaks at the DNA sensor, the DNA surface coverage was measured before and after immersing the sensor in the $\left[\mathrm{Cu}^{\mathrm{II}}(\mathrm{phen})_{2}\right]^{2+}$ nuclease assay. The experiments were performed in $10 \mathrm{mM}$ Tris- $\mathrm{HCl}, \mathrm{pH} \mathrm{7.4}$, and analysed using the aforementioned Tarlov method. The nuclease assays consisted of 10,20 or $50 \mu \mathrm{M}$ $\left[\mathrm{Cu}^{\mathrm{II}}(\text { phen })_{2}\right]^{2+}, 1 \mathrm{mM}$ ascorbic acid (AA) as the reductant and $1 \mathrm{mM} \mathrm{H}_{2} \mathrm{O}_{2}$ as the oxidant in $0.1 \mathrm{M} \mathrm{PB}, \mathrm{pH} 7.0$.

The DNA sensor was first immersed in $0.1 \mathrm{M} \mathrm{PB}, \mathrm{pH} 7.0$, at $37^{\circ} \mathrm{C}$ for 2 hours. After cooling and washing the DNA sensor for $10 \mathrm{~min}$, the DNA surface coverage was measured. This measurement yields the number of DNA molecules on the electrode surface after treating the sensor with the given conditions and before contact with the cleavage assay. Next, the DNA sensor was immersed in the nuclease assay at $37^{\circ} \mathrm{C}$ for 2 hours and, after cooling and washing, the DNA surface coverage was measured again. The washing step between cleavage and DNA surface coverage measurements are necessary to ensure that $\left[\mathrm{Cu}^{\mathrm{II}}(\mathrm{phen})_{2}\right]^{2+}$ is removed from the DNA layer and does not affect the interactions between DNA and RuHex. Typical CC data obtained at the DNA sensor is presented in figure 2. Two step chronocoulometry was used to reduce and then re-oxidize RuHex ions trapped in the DNA layer.

\section{Here Figure 2}

The plot of charge versus the square root of time can be constructed for each RuHex concentration and the intercepts determined (Figure 3).

\section{Here Figure 3}

The difference between the intercept in the absence and in the presence of RuHex is equal to $Q_{\text {ads. }}$ A plot of $Q_{\text {ads }}$ values versus RuHex concentration reveals the point when the DNA SAM is saturated with RuHex (Figure $4 \mathrm{a}$ ). When the $\mathrm{Q}_{\mathrm{ads}}$ value becomes constant, the DNA SAM is saturated with RuHex. The plot $C / Q_{a d s}$ versus $C$ (where $C$ is the concentration of RuHex) returns a linear plot according to Langmuir theory (Figure 4b). This plot can be used to calculate the reduction charge of RuHex obtained for the saturated DNA layer $\left(\mathrm{Q}_{\text {sat }}\right)$ required to determine the binding constant, between DNA and RuHex, and further calaculations (equation 3). The average binding constant for RuHex at DNA sensor was determined to be $0.45 \mu \mathrm{M}^{-1}$. This result indicates that RuHex binds to DNA relatively strongly in the given conditions. 


\section{Here Figure 4a and $4 b$}

The DNA surface coverage, after immersing the DNA sensor in the nuclease assay at a temperature of $37^{\circ} \mathrm{C}$, decreased significantly (Table 1). The decrease depends on the concentration of $\left[\mathrm{Cu}^{\mathrm{II}}(\text { phen })_{2}\right]^{2+}$. The DNA cleavage, with an average of $21 \%$, was observed after immersing the DNA sensor in a solution containing $20 \mu \mathrm{M}\left[\mathrm{Cu}^{\mathrm{II}}(\mathrm{phen})_{2}\right]^{2+}$. Thus, on average, 6 base pairs were cleaved from each immobilised DNA strand. After immersing the DNA sensor in the nuclease assay containing only $10 \mu \mathrm{M}\left[\mathrm{Cu}^{\mathrm{II}}(\text { phen })_{2}\right]^{2+}$, the DNA surface coverage decreased by $13 \%$. This lower DNA cleavage efficiency is due to smaller number of radicals generated in the solution containing lower $\left[\mathrm{Cu}^{\mathrm{II}}(\mathrm{phen})_{2}\right]^{2+}$ concentration. Moreover, after an exposure of the DNA sensor to a solution containing the higher $\left[\mathrm{Cu}^{\mathrm{II}}(\text { phen })_{2}\right]^{2+}$ concentration, $50 \mu \mathrm{M}$, DNA surface coverage decreases by $23 \%$. That is, 7 base pairs were cleaved from each DNA strand. The cleavage observed in a solution containing $20 \mu \mathrm{M}$ and $\left.50 \mu \mathrm{M}\left[\mathrm{Cu}^{\mathrm{II}} \text { (phen) }\right)_{2}\right]^{2+}$ is very similar, despite the significant difference in the concentration. This result indicates that the DNA layer is saturated with $20 \mu \mathrm{M}$ $\left[\mathrm{Cu}^{\mathrm{II}}(\text { phen })_{2}\right]^{2+}$ and this concentration can be used to estimate the nuclease activity of the compound.

\section{Here Table 1}

A number of conditions were checked to make sure that the observed cleavage is associated only with the interaction between DNA and $\left[\mathrm{Cu}^{\mathrm{II}}(\text { phen })_{2}\right]^{2+}$ in the presence of the exogenous reductant and oxidant (Table S1, Supplementary Information). The heating of the DNA sensor at $37^{\circ} \mathrm{C}$ for 2 hours did not cause significant changes in the DNA surface coverage. DNA cleavage was not observed when the experiment was performed in $0.1 \mathrm{M} \mathrm{PB}, \mathrm{pH} 7.0$, containing only $\left[\mathrm{Cu}^{\mathrm{II}}(\text { phen })_{2}\right]^{2+}$. Moreover, significant DNA cleavage was not registered when the experiment was performed in the buffer containing only a reductant or only an oxidant or both reductant and oxidant. Hence, a solution of reductant and an oxidant (without $\left.\left[\mathrm{Cu}^{\mathrm{II}}(\text { phen })_{2}\right]^{2+}\right)$ does not induce DNA cleavage. Similarly, significant DNA cleavage was not observed when the DNA sensor was immersed in the buffer containing only $\left[\mathrm{Cu}^{\text {II }}(\text { phen })_{2}\right]^{2+}$ and the oxidant $\left(\mathrm{H}_{2} \mathrm{O}_{2}\right)$. However, the DNA surface coverage decreased by approximately $15 \%$ in the solution containing only $\left[\mathrm{Cu}^{\mathrm{II}}(\mathrm{phen})_{2}\right]^{2+}$ and the reductant (ascorbic acid). The solution oxygen acted as the oxidant here. Thus, the $\left[\mathrm{Cu}^{\mathrm{II}}(\mathrm{phen})_{2}\right]^{2+}$ exhibits DNA nuclease properties only under specific conditions, i.e. in the presence of a reductant and an oxidant.

\subsection{Electrochemically induced cleavage}

It was reported by Fojta et al. (2002b) that transition metal ion complexes that interact with DNA can be electrochemically reduced within a DNA layer and, in the presence of oxygen, can lead to DNA cleavage. Hence, the electrochemical reduction of $\left[\mathrm{Cu}^{\mathrm{II}}(\mathrm{phen})_{2}\right]^{2+}$, intercalated within the DNA base pairs in an aerated solution, should promote cleavage of DNA in the absence of an external reductant and oxidant. In this experiment, the DNA sensor, together with a $\mathrm{Pt}$ wire counter and $\mathrm{Ag} / \mathrm{AgCl}$ reference electrode, were immersed in $0.1 \mathrm{M} \mathrm{PB}, \mathrm{pH} 7.0$, containing $20 \mu \mathrm{M}\left[\mathrm{Cu}^{\mathrm{II}}(\text { phen })_{2}\right]^{2+}$ and heated at $37^{\circ} \mathrm{C}$ for $20 \mathrm{~min}$. During the next five minutes of heating, a potential of $-0.205 \mathrm{~V}$ vs. $\mathrm{Ag} / \mathrm{AgCl}$ was applied to the DNA sensor. After cooling and washing the DNA sensor for 10 minutes, the DNA surface coverage was measured. The chosen potential of $-0.205 \mathrm{~V}$ vs. $\mathrm{Ag} / \mathrm{AgCl}$, based on SWV experiments (Fig. S3, Supplementary Information), ensures that $\left[\mathrm{Cu}^{\mathrm{II}}(\text { phen })_{2}\right]^{2+}$ is reduced in aerated solution at the DNA sensor. A $23 \%$ decrease in the DNA surface coverage was observed 
after applying the cathodic potential at DNA sensor in a solution containing $\left[\mathrm{Cu}^{\mathrm{II}}(\mathrm{phen})_{2}\right]^{2+}$ (Table 2), indicating a DNA cleavage event.

The mechanism of electrochemically induced DNA cleavage by cleavage agents was proposed by Yang et al. (2002):

$$
\begin{aligned}
{\left[\mathrm{Cu}^{\mathrm{II}}(\text { phen })_{2}\right]^{2+}+\mathrm{e}^{-} } & \longrightarrow\left[\mathrm{Cu}^{\mathrm{I}}(\text { phen })_{2}\right]^{+} \\
2\left[\mathrm{Cu}^{\mathrm{I}}(\text { phen })_{2}\right]^{+}+2 \mathrm{H}^{+}+\mathrm{O}_{2} & \longrightarrow 2\left[\mathrm{Cu}^{\mathrm{II}}(\text { phen })_{2}\right]^{2+}+\mathrm{H}_{2} \mathrm{O}_{2} \\
{\left[\mathrm{Cu}^{\mathrm{I}}(\text { phen })_{2}\right]^{+}+\mathrm{H}_{2} \mathrm{O}_{2} } & \longrightarrow\left[\mathrm{Cu}^{\mathrm{II}}(\text { phen })_{2}\right]^{2+}+\mathrm{HO}^{\circ}+\mathrm{HO}^{-}
\end{aligned}
$$

\section{Here Table 2}

The heating of the DNA sensor at $37^{\circ} \mathrm{C}$ for 20 minutes, and the application of the reduction potential, did not cause change in the DNA surface coverage in the absence of the $\left[\mathrm{Cu}^{\mathrm{II}}(\text { phen })_{2}\right]^{2+}$ (Table S2, Supplementary Information). DNA cleavage was not observed when the DNA sensor was immersed in $\left[\mathrm{Cu}^{\mathrm{II}}(\mathrm{phen})_{2}\right]^{2+}$ solution without electrochemical reduction (Table S2, Supplementary Information). Hence, the reduction of $\left[\mathrm{Cu}^{\mathrm{II}}(\mathrm{phen})_{2}\right]^{2+}$ to $\left[\mathrm{Cu}^{\mathrm{I}}(\text { phen })_{2}\right]^{+}$in aerated solution is necessary to cleave the DNA strands.

Additionally, methylene blue $\left(\mathrm{MB}^{+}\right)$was used as a control compound. Methylene Blue is also a known intercalator; however, unlike $\left[\mathrm{Cu}^{\mathrm{II}}(\text { phen })_{2}\right]^{2+}$, this compound does not follow Fentonlike reaction and cannot cleavage DNA strand. MB can be reduced at the DNA sensor via long-range electron transfer to leucomethylene blue (LMB).

$$
\mathrm{MB}^{+}+\mathrm{e}^{-}+\mathrm{H}^{+} \longrightarrow \mathrm{LMB}
$$

The DNA sensor was immersed in $0.1 \mathrm{M} \mathrm{PB}, \mathrm{pH} 7.0$, containing $20 \mu \mathrm{M} \mathrm{MB}^{+}$for 20 min and a potential of $-0.300 \mathrm{~V}$ vs. $\mathrm{Ag} / \mathrm{AgCl}$ was applied for 5 minutes. The chosen potential was based on a cyclic voltammetry measurement made in $\mathrm{MB}^{+}$solution at $37^{\circ} \mathrm{C}$ (data not shown). The DNA length did not change after interaction with $\mathrm{MB}^{+}$and applying a potential (Table S2, Supplementary Information). These results indicate that method presented in this paper can divide DNA cleavage agents from compounds that do not cause DNA cleavage, such as ordinary intercalators.

\subsection{Cleavage at G-C and A-T rich region strands}

The electrochemical cleavage was repeated at DNA strands containing guanine-cytosine $(\mathrm{G}-\mathrm{C})$ and adenine-thymine (A-T) rich regions to check if $\left[\mathrm{Cu}(\mathrm{II} \text { (phen })_{2}\right]^{2+}$ cleaves selectively at A-T or G-C bases. The cleavage was induced both chemically and electrochemically (Table 3). After an exposure of the DNA sensor to a solution containing $20 \mu \mathrm{M}$ $\left[\mathrm{Cu}^{\mathrm{II}}(\text { phen })_{2}\right]^{2+}, 1 \mathrm{mM}$ ascorbic acid (AA) and $1 \mathrm{mM} \mathrm{H}_{2} \mathrm{O}_{2}$ in $0.1 \mathrm{M} \mathrm{PB}, \mathrm{pH} 7.0$ and heating at $37^{\circ} \mathrm{C}$ for 2 hours, the DNA surface coverage decreased by $19 \%(6 \mathrm{bp})$ for both A-T and G-C rich region strands. The DNA sensor was also immersed in $0.1 \mathrm{M} \mathrm{PB}, \mathrm{pH} 7.0$, containing $20 \mu \mathrm{M}\left[\mathrm{Cu}^{\mathrm{II}}(\text { phen })_{2}\right]^{2+}$ and heated at $37^{\circ} \mathrm{C}$ for $20 \mathrm{~min}$ following applying potential $-0.205 \mathrm{~V}$ vs. $\mathrm{Ag} / \mathrm{AgCl}$ at this temperature for next $5 \mathrm{~min}$. After this electrochemical treatment, the DNA surface coverage decreased by $20 \%(6 \mathrm{bp})$ and $24 \%$ (7 bp) for A-T and G-C rich region strands, respectively. Lack of significant difference in the cleavage effectiveness of $\left[\mathrm{Cu}^{\mathrm{II}}(\text { phen })_{2}\right]^{2+}$ on both types of strands indicates that selective cleavage does not occur.

\section{Here Table 3}




\subsection{Control Measurement for Quantitation of DNA Immobilized at the Electrode}

The Tarlov method is based on calculating the number of RuHex molecules that adsorb at the DNA layer. However, RuHex can also adsorb at the bare gold electrode (Steel et al., 1998). Hence, the p-toluenethiol was used to backfill pinholes that remain on the electrode surface after DNA immobilisation to prevent any non-specific adsorption of RuHex at the bare electrode surface. The chronocoulometry measurements were performed at the bare gold electrode and at the p-toluenethiol-modified electrode in $10 \mathrm{mM}$ Tris- $\mathrm{HCl}, \mathrm{pH} \mathrm{7.4}$, in the absence and in the presence of $200 \mu \mathrm{M}$ RuHex.

The charge profiles obtained using chronocoulometry for the bare gold and p-toluenethiolmodified electrodes, in the presence and absence of RuHex, are different than the profiles obtained at the DNA sensor (Fig. S4, S5, S6, Supplementary Information). The Q ads values registered at the bare gold electrode were approximately $20 \mu \mathrm{C}$, while at the p-toluenethiolmodified electrode, was approximately $2 \mu \mathrm{C}$. These results indicate that RuHex does adsorb at the bare gold electrode surface, while, the p-toluenthiol largely prevents this adsorption. Hence, the $\mathrm{Q}_{\mathrm{ads}}$ values obtained for RuHex at DNA sensors are associated with the adsorption of RuHex at the DNA layer, not with the non-specific adsorption of RuHex at the bare electrode surface.

Additionally, the p-toluenethiol-modified electrode was tested in $0.1 \mathrm{M} \mathrm{PB}, \mathrm{pH} 7.0$, containing $0.2 \mathrm{mM} \mathrm{K}_{4} \mathrm{Fe}(\mathrm{CN})_{6}$. The oxidation and reduction wave was clearly visible in this solution at the bare gold electrode, while completely invisible at the p-toluenethiol-modified electrode (Fig. S7, Supplementary Information). This result indicates that the thiol covered the whole electrode surface and the electron exchange between ferrocyanide ions and the surface was blocked.

\section{Conclusions}

The $\left[\mathrm{Cu}^{\mathrm{II}}(\text { phen })_{2}\right]^{2+}$ redox waves observed at the DNA sensor indicates that this compound does interact with DNA and is accumulated in the DNA SAM.

The DNA surface coverage decreased approximately $21 \%$ after immersing the DNA sensor in the nuclease assay containing $\left.20 \mu \mathrm{M}\left[\mathrm{Cu}^{\mathrm{II}} \text { (phen) }\right)_{2}\right]^{2+}$, a reductant, and an oxidant at $37^{\circ} \mathrm{C}$ for 2 hours. The $\left[\mathrm{Cu}^{\mathrm{II}}(\text { phen })_{2}\right]^{2+}$ was shown to intercalate between DNA base pairs. When $\left[\mathrm{Cu}^{\mathrm{II}}(\text { phen })_{2}\right]^{2+}$ is reduced electrochemically from an aerated solution at $37^{\circ} \mathrm{C}$ DNA cleavage is also observed $(23 \%)$. The electrochemical reduction $\left[\mathrm{Cu}^{\mathrm{II}}(\mathrm{phen})_{2}\right]^{2+}$ excludes the necessity for the addition of exogenous reductants and oxidants, in the nuclease assay.

The experiments proved that the presented method - calculating the DNA surface coverage before and after exposure to the DNA cleavage agent - can provide the quantitative information about the nuclease efficacy of potential anti-cancer drugs.

We believe that these results represent an important step in the development of DNA damage sensors. Future work will be focused on quantifying the nuclease activity of a range of DNA bioinorganic DNA nuclease complexes and further validation will be obtained using bioinorganic complexes that do not exhibit DNA nuclease activity. An array of DNA sensors will be fabricated for the simultaneous quantitation DNA nuclease efficacy of a range of bioinorganic complexes. Miniaturisation of these DNA sensor arrays will then be carried out. This reported method, due to its simplicity and rapid response, has the potential to be utilised prior to the expensive cancer cell line assays.

\section{Acknowledgements:}

Anna Banasiak acknowledges $\mathrm{PhD}$ scholarship from Dublin Institute of Technology (Fiosraigh Award, Grant code: PB03979). 


\section{References}

Abreu, F.C., Goulart, M.O.F., Oliveira-Brett, A.M., 2002. Biosens. Bioelectron. 17, 913-919. Ausubel, F.M., Brent, R., Kingston, R.E., Moore, D.D., Smith, J.A., Seidman, J.G., Struhl, K., 1989. Current protocols in molecular biology, John Wiley \& Sons, New York, p. A.3.3-4. Brabec, V., 2000. Electrochim. Acta. 45, 2929-2932.

Carter, T.M., Rodriguez, M., Bard, J.A., 1989. J. Am. Chem. Soc. 111, 8901-8911.

Congur, G., Erdem, A., Mese, F., 2015. Bioelectrochem. 102, 21-28.

Diculescu, V.C., Vivan, M., Oliveira-Brett, A.M., 2006. Electroanal. 18, 1963-1970.

Diculescu, V.C., Chiorcea-Paquim, A., Oliveira-Brett, A., 2016. Trends Anal. Chem. 79, 2336.

Drummond, T.G., Hill, M.G., Barton, J.K., 2003. Nat. Biotechnol. 21, 1192-1198.

Erdem, A., Congur, G., 2013. Int. J. Biol. Macromol. 61, 295-301.

Erdem, A., Ozsoz, M., 2001. Anal. Chim. Acta. 437, 107-114.

Erdem, A., Ozsoz, M., 2002. Electroanal. 14, 965-974.

Erts, D., Polyakov, B., Olin, H., Tuite, E., 2003. J. Phys. Chem. B. 107, 3591-3597.

Fojta, M., Havran, I., Palecek, E., 1997. Electroanal. 9, 1033-1034.

Fojta, M., Stankova, V., Palecek, E., Mitas, J., Koscielniak, P., 1998. Talanta. 46, 155-161.

Fojta, M., Kubicarova, T., Palecek, E., 1999. Electroanal. 11, 1005-1012.

Fojta, M., Havran, L., Fulneckova, J., Kubicarova, T., 2000a. Electroanal. 12, 926-934.

Fojta, M., Kubicarova, T., Palecek, E., 2000b. Biosens. Bioelectron. 15, 107-115.

Fojta, M., 2002a. Electroanal. 14, 1449-1463.

Fojta, M., Havran, L., Kubicarova, T., Palecek, E., 2002b. Bioelectrochem. 55, 25-27.

Fojta, M., Danhel, A., Havran, L., Vyskocil, V., 2016. Trends Anal. Chem. 79, 160-167.

Gibson, D., 2002. Pharmacogenomics J. 2, 275-276.

Gowda, S.K.R, Mathew, B.B., Sudhamani, C.N., Bhojya Naik, H.S., 2014. J. Biomed. Biotechnol. 2, 1-9.

Herne, T.M., Tarlov, M.J., 1997. J. Am. Chem. Soc. 119, 8916-8920.

Janiszek, D., Karpinska, M.M., Niewiadomy, A., Girstun, A., Elzanowska, H., MajZurawska, M., Kulesza, P.J. 2016. Electrochim. Acta. 8, 422-434.

Jelen, F., Erdem, A., Palecek, E., 2002. Bioelectrochem. 55, 165-167.

Kelley, O.S., Barton, K.J., Jackson, M.N., McPherson, D.L., Potter, B.A., Spain, M.E., Allen, J.M., Hill, M.G., 1998. Langmuir Letters. 14, 6781-6784.

Labuda, J., Buckova, M., Vanickova, M., Mattusch, J., Wennrich, R., 1998. Electroanal. 11, 101-107.

La-Scalea, M.A., Serrano, S.H.P., Ferreira, E.I., Oliveira-Brett, A.M., 2002. J. Pharm. Biomed. Anal. 29, 561-568.

Li, Z., Zhang, L., Cheng, G., Yang, X., Zhou, J., Chen, Y., 2014. Int. J. Electrochem. Sci. 9, $4241-4250$.

Liu, T., Barton, J.K., 2005. J. Am. Chem. Soc. 127, 10160-10161.

Lloyd, D.R., Carmichael, P.L., Phillips, D.H., 1998. Chem. Res. Toxicol. 11, 420-427.

Marin, D., Perez, P., Teijeiro, C., Palecek, E., 1998. Biophys. Chem. 75, 87-95.

Marshall, L.E., Graham, D.R., Reich, K.A., Sigman, D.S., 1981. Biochem. 20, 244-250.

Molphy, Z., Prisecaru, A., Slator, C., Barron, N., McCann, M., Colleran, J., ... Kellett, A., 2014. Inorg. Chem. 53, 5392-5404.

Molphy, Z., Slator, C., Chatgilialoglu C., Kellett, A., 2015. Front. Chem. 3, 1-9.

Moura-Melo, S., Miranda-Castro, R., de-los-Santos-Alvarez, N., Miranda-Ordieres, J.A., Dos

Santos Junior, J.R., da Silva Fonseca, R.A., Lobo-Castanon, M.J., 2015. Anal. Chem. 87,

8547-8554.

Oliveira, S.C.B., Oliveira-Brett, A.M., 2010. Anal. Bioanal. Chem. 398, 1633-1641. 
Oliveira-Brett, A.M., Serrano, S.H.P., Macedo, T.A., Raimundo, D., Marquesi, M.H., LaScalea, M.A., 1996. Electroanal. 8, 992-995.

Oliveira-Brett, A.M., Macedo, T.R.A., Raimundo, D., Marques, M.H., Serrano, S.H.P., 1998. Biosens. Bioelectron. 13, 861-867.

Oliveira-Brett, A.M., Vivan, M., Fernandes, I.R., Piedade, J.A.P., 2002. Talanta. 56, 959-970.

Oliveira-Brett, A.M., Diculescu, V.C., 2004. Bioelectrochem. 64, 143-150.

Palecek, E., Bartosik, M., 2012. Chem. Rev. 112, 3427-3481.

Patrick, G.L., 2013. An introduction to medicinal chemistry, fifth ed. Oxford University Press, United Kingdom.

Perez, P., Teijeiro, C., Marin, D., 1999. Chem. Biol. Interact. 117, 65-81.

Pividori, M.I., Merkoc, A., Alegret, S., 2000. Biosens. Bioelectron. 15, 291-303.

Prisecaru, A., Devereux, M., Barron, N., McCann, M., Colleran, J., Casey, A.... Kellett, A., 2012. Chem. Commun. 48, 6906-6908.

Prisecaru, A., McKee, V., Howe, O., Rochford, G., McCann, M., Colleran, J., ... Kellett, A., 2013. J. Med. Chem. 56, 8599-8615.

Que, B.G., Downey, K.M., So, A.G., 1980. Biochem. 19, 5987-5991.

Reddy, K.H., Reddy, P.S., Babu, P.R., 1999. J. Inorg. Biochem. 77, 169-176.

Rodriguez, M., Kodadek, T., Torres, M., Bard, A.J., 1990. Bioconjugate Chem. 1, 123-131.

Sigma-Aldrich, Protocol for Annealing Oligonucleotides, source (last accessed February 2018): http://www.sigmaaldrich.com/technical-documents/protocols/biology/annealingoligos.html.

Sigman, D.S., Graham, D.R., Aaurora, V.D., Stern, A.M., 1979. J. Biol. Chem. 254, 1226912272.

Steel, A.B., Herne, T.M., Tarlov, M.J., 1998. Anal. Chem. 70, 4670-4677.

Steel, A.B., Herne, T.M., Tarlov, M.J., 1999. Bioconjugate Chem. 10, 419-423.

Steel, A.B., Levicky, R.L., Herne, T.M., Tarlov, M.J., 2000. Biophys. J. 79, 975-981.

Treadway, C.R., Hill, M.G., Barton, J.K., 2002. Chem. Phys. 281, 409-428.

Wang, J., Ozsoz, M., Cai, X., Rivas, G., Shiraishi, H., Grant, D.H., ... Palecek, E., 1998. Biosens. Bioelectron. 45, 33-40.

Yang, Z.-S., Yu, J.-S., Chen, H.-Y., 2002. Electroanal. 14, 747-751.

Yu, H.-Z., Luo, C.-Y., Sankar, C.G., Sen D., 2003. Anal. Chem. 75, 3902-3907.

Zhang, Z.-L., Pang, D.-W., Zhang, R.Y., 2002. Bioconjugate Chem. 13, 104-109. 


\section{Figures and Captions}

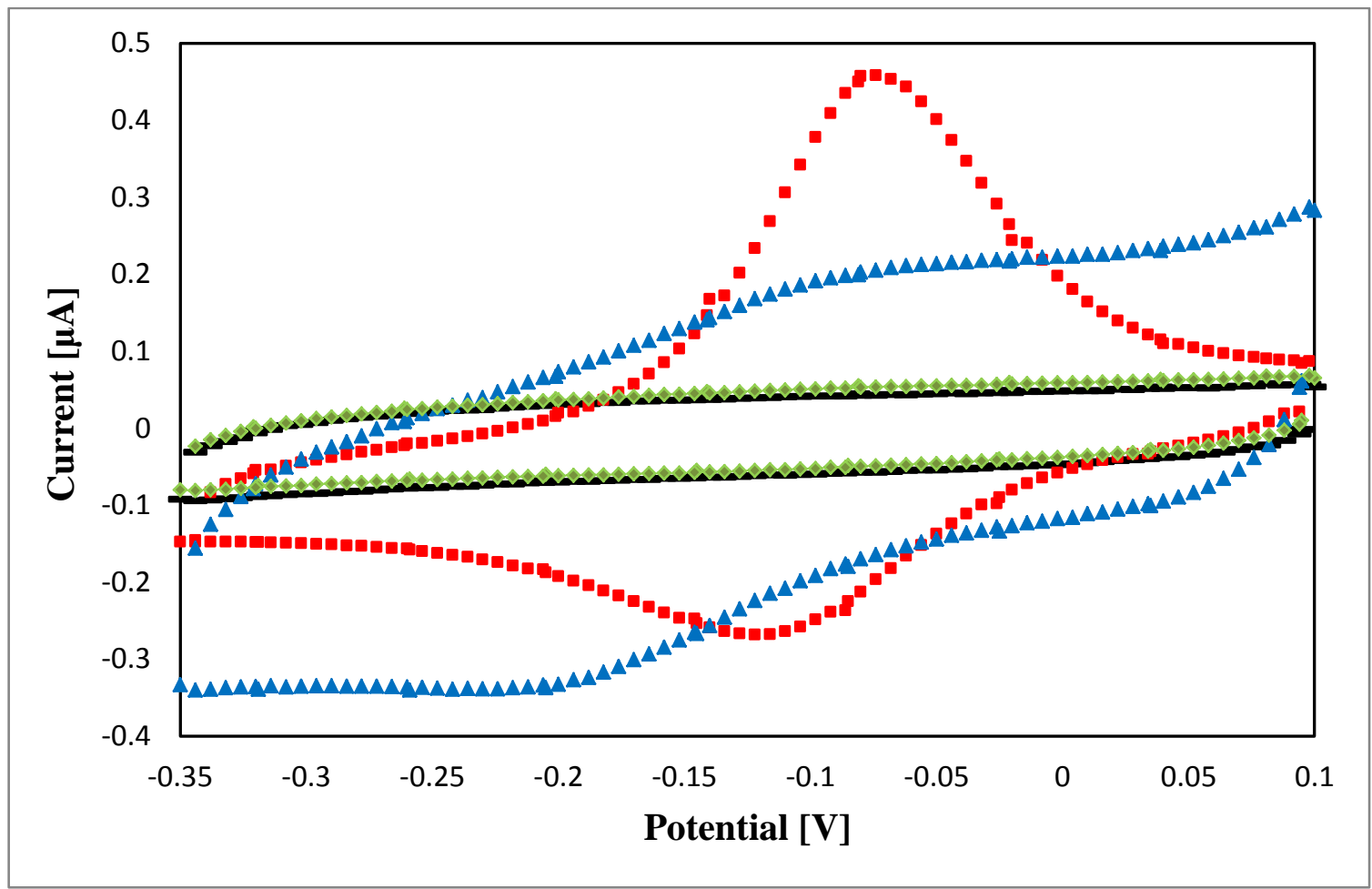

Figure 1. Typical CV voltammograms registered in $0.1 \mathrm{M} \mathrm{PB}, \mathrm{pH} 7.0$, at a DNA sensor (solid black trace), and in $0.1 \mathrm{M} \mathrm{PB}, \mathrm{pH} 7.0$, containing $20 \mu \mathrm{M}\left[\mathrm{Cu}^{\mathrm{II}}(\text { phen })_{2}\right]^{2+}$ at a bare gold electrode (triangular blue trace) and at the DNA sensor (squared red trace), and in pure buffer again after washing the DNA sensor for 20 minutes (rhombic green trace); scan rate: $0.1 \mathrm{~V} \cdot \mathrm{s}^{-1}$. The PB was deoxygenated in all measurements.

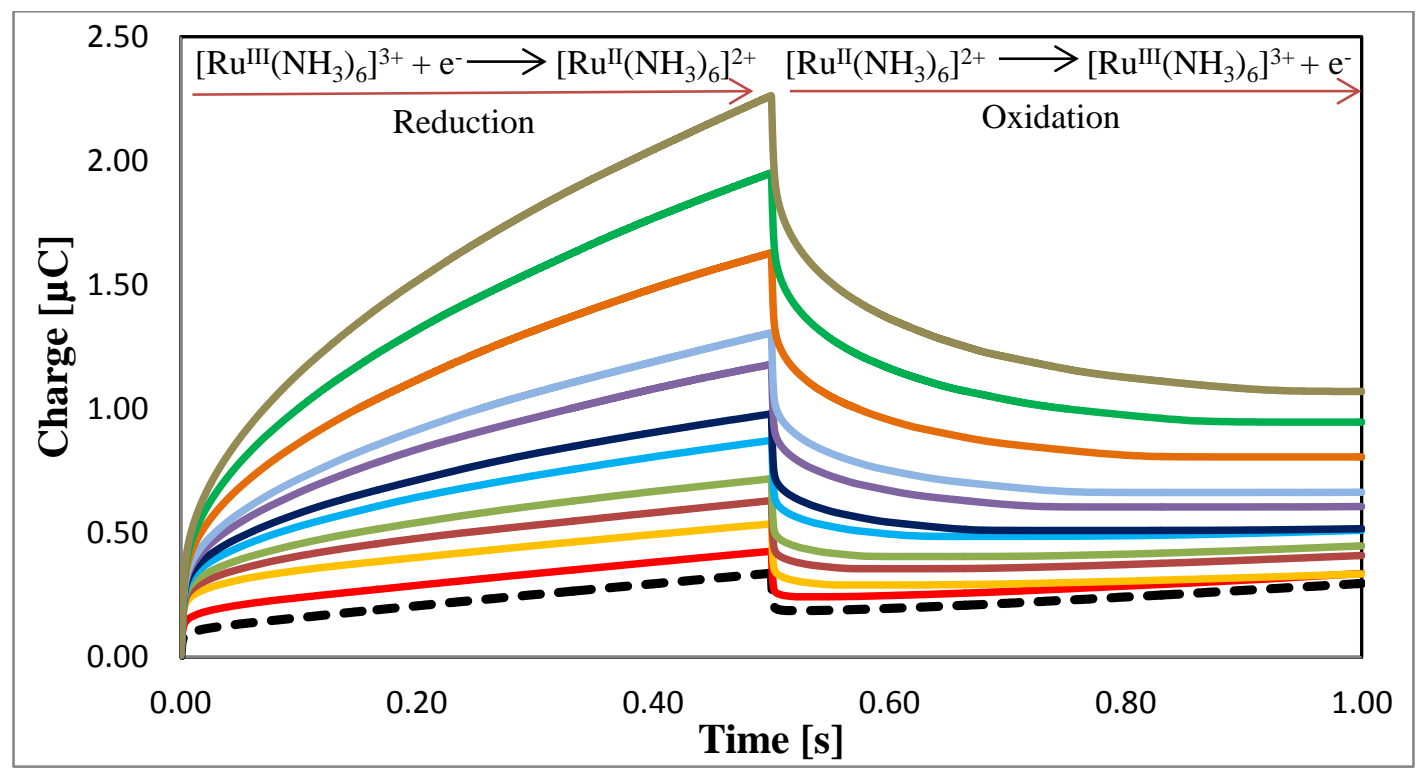

Figure 2. Typical Q versus t plots obtained at a DNA sensor in $10 \mathrm{mM}$ Tris- $\mathrm{HCl}, \mathrm{pH}$ 7.4. The dashed trace was registered in the absence of RuHex, the other traces in varied concentrations of RuHex $(0.5 \mu \mathrm{M}-250 \mu \mathrm{M})$. 


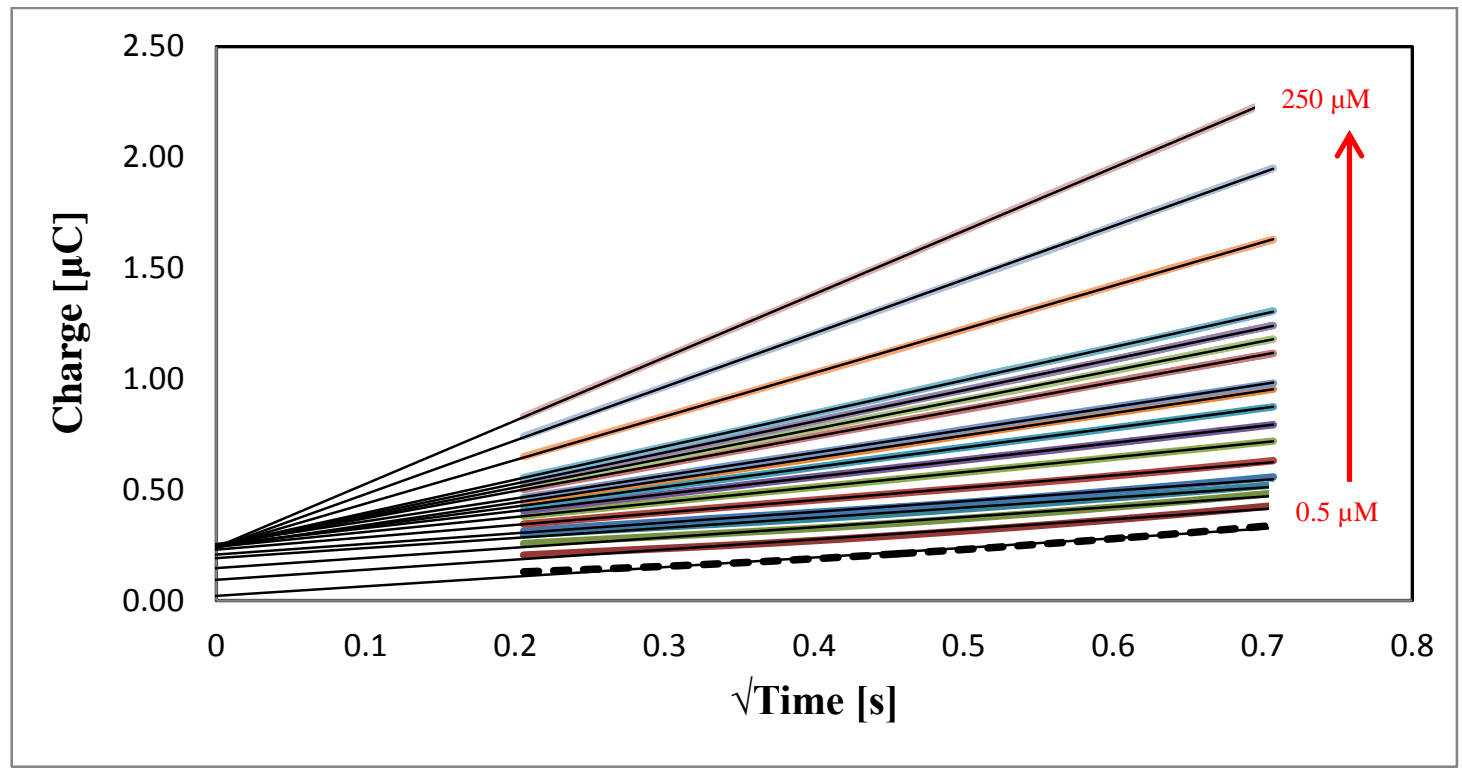

Figure 3. Typical $\mathrm{Q}$ versus $\sqrt{t}_{\mathrm{t}}$ plots obtained at a DNA sensor in $10 \mathrm{mM}$ Tris-HCl, $\mathrm{pH}$ 7.4. The dashed trace was registered in the absence of RuHex, the other traces in varied concentrations of RuHex $(0.5 \mu \mathrm{M}-250 \mu \mathrm{M})$. The intercepts in the presence of RuHex minus the intercept in the absence of RuHex is equal to $\mathrm{Q}_{\text {ads }}$. 

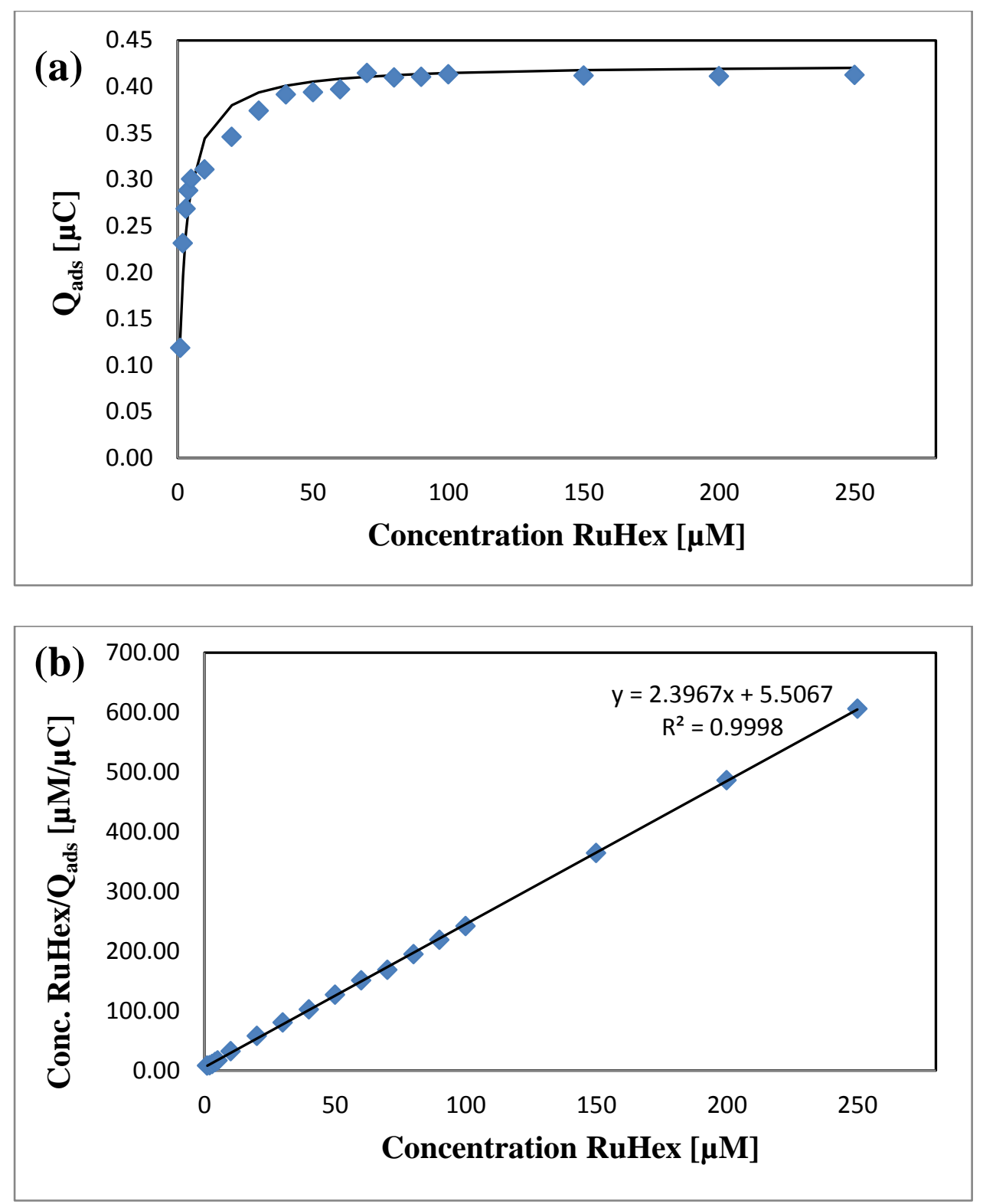

Figure 4. (a) Typical $\mathrm{Q}_{\text {ads }}$ versus RuHex concentration plot obtained at a DNA sensor in $10 \mathrm{mM}$ Tris- $\mathrm{HCl}, \mathrm{pH} 7.4$, the concentration of RuHex was varied from $0.5 \mu \mathrm{M}$ to $250 \mu \mathrm{M}$. (b) These data were plotted according to Langmuir theory. 


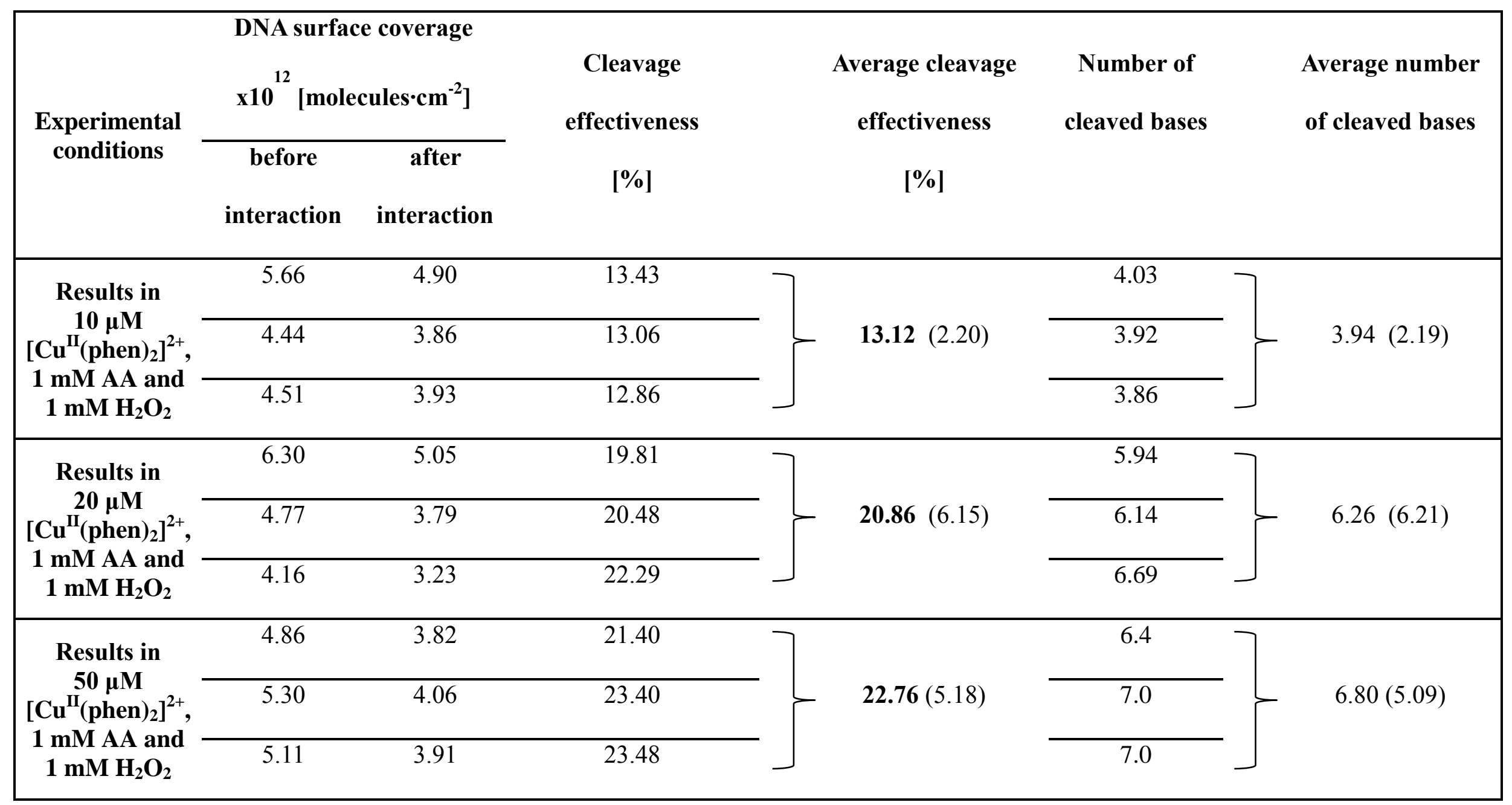

Table 1. The DNA surface coverage before and after immersing a DNA sensor in the nuclease assay for 2 hours at $37^{\circ} \mathrm{C}$ and the percentage amount of cleaved DNA together with the number of cleaved bases $(30 \mathrm{bp}=100 \%)$. \%SD values are given in brackets. 


\begin{tabular}{|c|c|c|c|c|c|c|}
\hline \multirow{3}{*}{$\begin{array}{l}\text { Experimental } \\
\text { conditions }\end{array}$} & DNA surf & coverage & \multirow{3}{*}{$\begin{array}{c}\text { Cleavage } \\
\text { effectiveness } \\
{[\%]}\end{array}$} & \multirow{3}{*}{$\begin{array}{c}\text { Average cleavage } \\
\text { effectiveness } \\
{[\%]}\end{array}$} & \multirow{3}{*}{$\begin{array}{l}\text { Number of } \\
\text { cleaved bases }\end{array}$} & \multirow{3}{*}{$\begin{array}{l}\text { Average number } \\
\text { of cleaved bases }\end{array}$} \\
\hline & \multicolumn{2}{|c|}{$\mathrm{x10}^{12}\left[\right.$ molecules $\left.\cdot \mathrm{cm}^{-2}\right]$} & & & & \\
\hline & $\begin{array}{c}\text { before } \\
\text { interaction }\end{array}$ & $\begin{array}{c}\text { after } \\
\text { interaction }\end{array}$ & & & & \\
\hline \multirow{3}{*}{$\begin{array}{c}20 \mu \mathrm{M} \\
{\left[\mathrm{Cu}^{\mathrm{II}}(\mathrm{phen})_{2}\right]^{2+},} \\
\text { after applying } \\
\text { potential }\end{array}$} & 2.51 & 1.93 & 23.10 & \multirow{3}{*}{$23.22(3.86)$} & 6.93 & \multirow{3}{*}{$6.97(3.83)$} \\
\hline & 4.22 & 3.20 & 24.17 & & 7.25 & \\
\hline & 3.26 & 2.53 & 22.39 & & 6.72 & \\
\hline \multicolumn{4}{|c|}{ Without $\left[\mathrm{Cu}^{\mathrm{II}}(\text { phen })_{2}\right]^{2+}$, after applying potential } & \multicolumn{3}{|c|}{ No cleavage observed } \\
\hline \multicolumn{4}{|c|}{$\begin{array}{c}20 \mu \mathrm{M}\left[\mathrm{Cu}^{\mathrm{II}}(\text { phen })_{2}\right]^{2+} \text { without applying potential and external } \\
\text { oxidant or reductant }\end{array}$} & \multicolumn{3}{|c|}{ No cleavage observed } \\
\hline
\end{tabular}

Table 2. The DNA surface coverage before and after immersing a DNA sensor in $20 \mu \mathrm{M}\left[\mathrm{Cu}^{\mathrm{II}}(\text { phen })_{2}\right]^{2+}$ for 25 minutes at $37^{\circ} \mathrm{C}$ and applying a potential of $-0.205 \mathrm{~V}$ vs. $\mathrm{Ag} / \mathrm{AgCl}$ for $5 \mathrm{~min}$, and the percentage amount of cleaved DNA together with the number of cleaved bases $(30 \mathrm{bp}=$ $100 \%$ ). RSD values are given in brackets. 


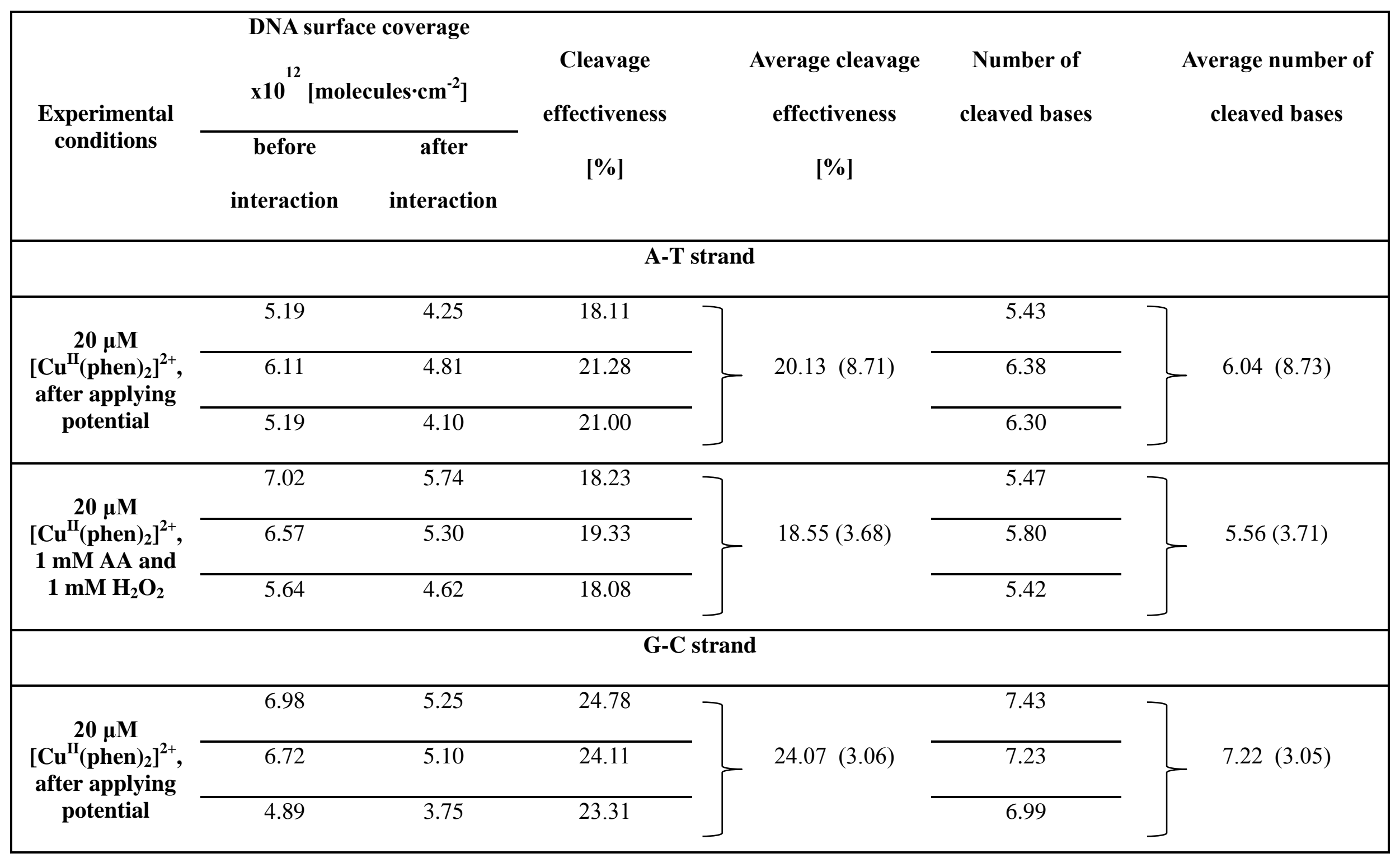




\begin{tabular}{|c|c|c|c|c|c|c|}
\hline \multirow{2}{*}{ 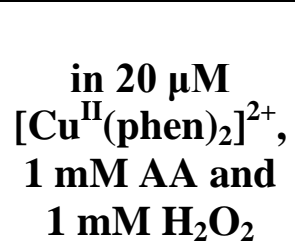 } & 7.56 & 6.15 & 18.65 & \multirow[b]{2}{*}{$18.75(1.18)$} & 5.60 & \multirow[b]{2}{*}{$5.63(1.14)$} \\
\hline & 6.51 & 5.30 & 18.59 & & 5.58 & \\
\hline
\end{tabular}

Table 3. The DNA surface coverage before and after chemically and electrochemically induced cleavage at A-T and G-C rich region strands and the percentage amount of cleaved DNA together with the number of cleaved bases $(30 \mathrm{bp}=100 \%)$. RSD values are given in brackets. 